\title{
Monitoring of Mercury and Arsenic in Water Samples from Proximity to Abandoned Cinnabar Mine
}

\author{
Pavlína Pelcová $^{1}$, Vendula Smolíková ${ }^{1,2}$, Andrea Ridošková ${ }^{1,3}$, Jana Hrachovinová $^{1}$, Jan Grmela ${ }^{4}$ \\ ${ }^{1}$ Department of Chemistry and Biochemistry, Mendel University in Brno \\ Zemědělská 1, Brno, Czech Republic \\ pavlina.pelcova@mendelu.cz; vendula.smolikova@mendelu.cz; andrea.ridoskova@mendelu.cz; \\ jana.hrachovinova@mendelu.cz \\ ${ }^{2}$ Central European Institute of Technology, Brno University of Technology \\ Purkynova 123, Brno, Czech Republic \\ ${ }^{3}$ Central European Institute of Technology, Mendel University in Brno \\ Zemědělska 1, CZ-61300, Brno, Czech Republic \\ ${ }^{4}$ Department of Zoology, Fisheries, Hydrobiology and Apiculture \\ Zemědělská 1, Brno, Czech Republic \\ jan.grmela@mendelu.cz
}

\begin{abstract}
Concentrations of mercury and arsenic were monitored in water samples from the Záskalská water reservoir (Czech Republic) and its tributaries. The total mercury concentration in the reservoir ranged between $0.06-0.11 \mu \mathrm{g} \mathrm{L}^{-1}$ and in tributaries between $0.14-$ $0.20 \mu \mathrm{g} \mathrm{L}^{-1}$. The effect of water erosion from abandoned cinnabar mine on mercury concentration in tributaries and reservoir was observed. The arsenic concentrations in water samples were between $0.21-0.54 \mu \mathrm{g} \mathrm{L}{ }^{-1}$. The $98 \pm 10 \%$ of arsenic concentration in the water was determined as potentially bioavailable, whereas only $7-20 \%$ of the total mercury concentration in the water was determined as bioavailable using diffusive gradients in thin films technique.
\end{abstract}

Keywords: Heavy metal, Cinnabar mine, Water sample, Metal bioavailability.

\section{Introduction}

Although the cinnabar mine is abandoned and there is no active mining, the surrounding environment can be significantly contaminated by mercury and other metals (iron, cadmium, lead, arsenic, etc.), which are still released into surrounding environment. The dominant form of mercury which is transported from mine waste is colloidal $\mathrm{HgS}$, in contrast to arsenic, which is mostly attached to colloidal Fe oxides [1]. Although cinnabar ( $\mathrm{HgS})$ is classified as a non-mobile form of mercury, the transformation of $\mathrm{HgS}$ into more toxic and bioavailable mercury forms can occur in the aquatic environment [2,3]. The physicochemical properties, as well as toxicity and bioavailability of mercury and arsenic chemical forms (species), vary widely and are influenced by various external factors, e.g. $\mathrm{pH}$, the concentration of sulfide, chloride, dissolved organic matter (DOC), and iron, redox potential (Eh), temperature, biota composition, etc. [4].

The main aim of this study was the assessment of mercury and arsenic contamination in the aquatic ecosystem of the Záskalská water reservoir. The Záskalská water reservoir is located at the foothills of Jedová hora (Brdy, Czech Republic), where mercury ore mining was carried out in the $18^{\text {th }}$ and $19^{\text {th }}$ centuries, thus an increased risk of contamination can be expected here. The contamination was evaluated by the determination of mercury and arsenic concentration in the grab sample of water as well as by the in-situ determination of mobile species of metals in water using the diffusive gradients in thin films technique (DGT).

\section{Experimental}

\section{1. Sampling sites}

The water samples were collected from the Záskalská water reservoir (Brdy, Czech Republic) and from its tributaries from June to September 2019. Four sampling sites (no. 1-4) were selected in the reservoir and three sampling sites (no. 5-7) were selected on tributaries. The sampling sites (no. 1-3) were selected near the main tributaries. The sampling 
site no. 4 was selected approximately $250 \mathrm{~m}$ away from the tributaries. The GPS coordinates of sampling sites are given in Table 1. The DGT sampling units were placed in the mesocosm of the reservoir on sampling sites no. 1-3.

Table 1: The GPS coordinates of sampling sites.

\begin{tabular}{|l|l|l|l|}
\hline Sampling site & GPS coordinates & Sampling site & GPS coordinates \\
\hline reservoir no. 1 & $49.7894117 \mathrm{~N}, 13.8808394 \mathrm{E}$ & tributary no. 5 & $49.7894394 \mathrm{~N}, 13.8816119 \mathrm{E}$ \\
\hline reservoir no. 2 & $49.7885667 \mathrm{~N}, 13.8813864 \mathrm{E}$ & tributary no. 6 & $49.7887744 \mathrm{~N}, 13.8841331 \mathrm{E}$ \\
\hline reservoir no. 3 & $49.7884906 \mathrm{~N}, 13.8804317 \mathrm{E}$ & tributary no. 7 & $49.7865650 \mathrm{~N}, 13.8825881 \mathrm{E}$ \\
\hline reservoir no. 4 & $49.7891831 \mathrm{~N}, 13.8784319 \mathrm{E}$ & & \\
\hline
\end{tabular}

\section{2. Sample preparation}

The water samples were collected into acid-cleaned glass bottles. The samples were transported to the laboratory in a refrigerator $\left(5^{\circ} \mathrm{C}\right)$. The water samples were filtrated through a PTFE syringe filter $(0.45 \mu \mathrm{m})$, acidified to $1 \%(\mathrm{v} / \mathrm{v}) \mathrm{HNO}_{3}$ concentration (VWR, Czech Republic) and stored under refrigeration until analysis.

\section{3. The DGT units}

The DGT units (piston type: $3.14 \mathrm{~cm}^{2}$ exposure area, supplied by DGT Research Ltd.) and polyethersulfone (PES) membrane filters $(0.45 \mu \mathrm{m}$ pore size and $0.013 \mathrm{~cm}$ thickness, supplied by Pall Corporation, USA) were used. The agarose diffusive gel and polyacrylamide resin gel containing cation-exchange resins Ambersep GT74 were used for the determination of bioavailable forms of mercury. Polyacrylamide diffusive gel and polyacrylamide resin gel containing iron oxide-hydroxide resin Lewatit FO 36 were used for the determination of arsenic. The DGT gels (diffusive as well as resin) were manufactured in-house and their preparation is described in detail in [5].

\section{4. Analytical Procedures}

Analytes were eluted from DGT resin gels by microwave-assisted extraction (Ethos Sel, Milestone, Italy). To release the arsenic from the resin gels, the mixture of sodium hydroxide $\left(10 \mathrm{~g} \mathrm{~L}^{-1}\right)$ and sodium chloride $\left(10 \mathrm{~g} \mathrm{~L}^{-1}\right)$ at $130{ }^{\circ} \mathrm{C}$ for 16 min was used. To release the mercury species the mixture of $6 \mathrm{~mol} \mathrm{~L}^{-1} \mathrm{HCl}+0.1 \mathrm{~mol} \mathrm{~L}^{-1} \mathrm{NaCl}$ at $60{ }^{\circ} \mathrm{C}$ for 20 min was used.

The atomic absorption spectrometry (AMA 254, Altec Praha, Czech Republic) was used for the determination of total mercury concentration in water samples and DGT resin gels. The determination is described in detail in our previous work [5].

The high-performance liquid chromatography hyphenated to atomic fluorescence spectrometry (HPLC-CV-AFS, PerkinElmer, USA, PS Analytical Ltd., UK) was used for speciation analysis of mercury. The determination is described in detail in [5].

The electrothermal atomic absorption spectrometry (ET-AAS) (280Z AA, Agilent Technologies, USA) was used for the determination of arsenic. The parameters of the ET-AAS method are described in detail in [6].

\section{5. Statistical Analysis}

Data were compared by Student's t-test. The statistical significance difference was declared for p-value $<0.05$.

\section{Results and Discussion}

\section{1. Mercury and arsenic concentration in grab water samples}

Total mercury concentrations in water samples from the Záskalská water reservoir (sampling from June to July 2019) ranged between $0.06-0.11 \mu \mathrm{g} \mathrm{L}^{-1}$ (Fig. 1). The median value of total mercury concentration in the Záskalská reservoir was $0.09 \mu \mathrm{g} \mathrm{L}^{-1}$. Statistically non-significant differences of mercury concentrations were observed between sampling sites no. 13. Statistically significantly lower concentration of total mercury was observed in sampling site no. 4. We assume that lower concentration of total mercury in sampling site no. 4 has a relationship with a greater distance of this sampling site from the tributaries, because the tributaries may represent a potential source of contamination of the reservoir. 


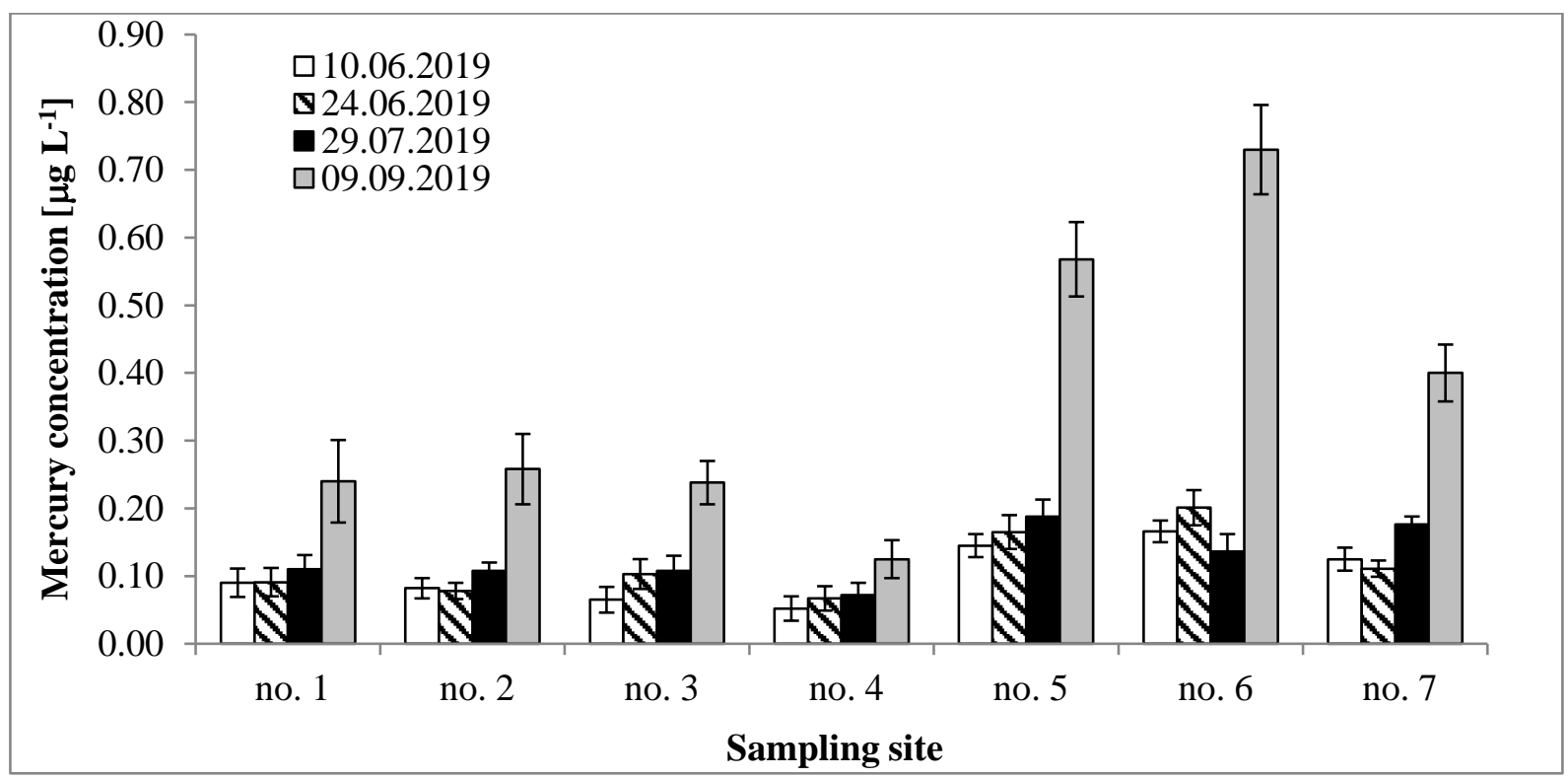

Fig. 1: Mercury concentration in water samples collected from the Záskalská reservoir (no. 1-4) and tributaries (no. 5-7).

Moreover, the statistically significantly higher concentration of mercury was observed in grab water samples which were collected in September 2019 (Fig. 1). The median value of total mercury concentration in the Záskalská reservoir was $0.24 \mu \mathrm{g} \mathrm{L}^{-1}$. We assume that a statistically higher concentration of mercury in water samples is associated with a larger content of mercury rich particles flowing into the water reservoir because water sampling in September was carried out under heavy rain. The rainfalls were about $40 \mathrm{~mm}$ during the period from $7^{\text {th }}$ to $9^{\text {th }}$ September. Concurrently, the significantly higher inflow of water from tributaries into the water reservoir was observed in September.

Total mercury concentrations in water samples from tributaries ranged between $0.14-0.20 \mu \mathrm{g} \mathrm{L}^{-1}$ with median value of $0.16 \mu \mathrm{g} \mathrm{L}^{-1}$, and $0.40-0.73 \mu \mathrm{g} \mathrm{L}{ }^{-1}$ with a median value of $0.57 \mu \mathrm{g} \mathrm{L}^{-1}$ (sampling during June to July 2019 and September 2019, respectively) (Fig.1).

Statistically significantly higher concentrations of total mercury were observed in water samples collected from tributaries no. 5 and 6. Tributary no. 5 is the water drainage from the abandoned cinnabar mine and tributary no. 6 flows in the foothills of Jedová hora directly under the abandoned cinnabar mine. The total mercury concentration in the water samples from tributary no. 7 was not statistically different from mercury concentrations determined in water samples taken from the Záskalská reservoir. Only $\mathrm{Hg}^{2+}$ was determined in water samples. The concentration of methylmercury was below the limit of detection $\left(0.1 \mu \mathrm{g} \mathrm{L}{ }^{-1}\right)$.

The median value of total mercury concentration in water samples collected from the reservoir from June and July exceeded the maximum limit of mercury $\left(0.07 \mu \mathrm{g} \mathrm{L}^{-1}\right)$ set out by the Government Regulation (CZ) No. 401/2015 by about $29 \%$. The total mercury concentrations in water samples from tributaries exceeded the limit 2.3times. However, during the rain, the maximum limit of mercury in the reservoir was exceeded 3.4times and 8.1times in the tributaries.

The arsenic concentrations in water samples were between $0.21-0.54 \mu \mathrm{g} \mathrm{L}^{-1}$. The maximum limit of arsenic in water as set by the Government Regulation (CZ) No. 401/2015 is $11 \mu \mathrm{g} \mathrm{L}^{-1}$ and therefore, the arsenic concentrations in water samples did not exceed the legislative limit.

\section{2. Mercury and arsenic bioavailability in water samples}

The DGT technique was used for the evaluation of mercury and arsenic bioavailability. The $98 \pm 10 \%$ of arsenic concentration in the water was available to the DGT and can be considered as bioavailable, whereas only $7-20 \%$ of mercury 
bioavailable forms were determined. The mercury bioavailability in aquatic ecosystems can be significantly affected by the strong binding to natural organic matter, sulfide and chloride ions [4]. We assume that a high concentration of these substances reduces mercury bioavailability in the environment.

Long-term (more than 14 days) mercury accumulation into DGT units was significantly influenced by the formation of biofilm on the DGT units. After more than 14 days of accumulation, there was observed an $80 \%$ decrease in the accumulated mass of mercury, whereas only a $6.1 \%$ decrease in the accumulated mass of arsenic after 49 days of accumulation was observed. Experiments to prevent biofilm formation on DGT units will be performed in the near future.

\section{Conclusion}

The aquatic ecosystem Záskalská seems to be affected by the high concentration of mercury from its tributaries. Mercury enters into tributaries mainly through water erosion from abandoned cinnabar mine. Mercury is probably accumulated in sediments, and so sediment samples may be another useful environmental indicator.

\section{Acknowledgements}

This research was financially supported by the project Czech Science Foundation (19-11528S), and by the project PROFISH CZ.02.1.01/0.0/0.0/16_019/0000869, which is financed by European Regional Development Fund in the Operational Programme Research, Development and Education and The Czech Ministry of Education, Youth and Sports.

\section{References}

[1] G. V. Lowry, S. Shaw, C. S. Kim, J. J. Rytuba, G. E. Brown, "Macroscopic and microscopic observations of particlefacilited mercury transport from New Idria sulphur bank mercury mine tailings," Environ. Sci. Technol., vol. 38, pp. 5101-5111, 2004.

[2] R. Fernandez-Martinez, J. Loredo, A. Ordonez, M. I. Rucandio, "Mercury availability by operationally defined fractionation in granulometric distributions of soils and mine wastes from an abandoned cinnabar mine," Environ. Sci.:Processes Impacts, vol. 16, pp. 1069-1075, 2014.

[3] D. Kocman, M. Horvat, J. Kotnik, "Mercury fractionation in contaminated soils from the Idrija mercury mine region," J. Environ. Monit., vol. 6, pp. 696-703, 2004.

[4] P. Houserová, K. Janák, P. Kubáň, J. Pavlíčková, V. Kubáň, "Chemical forms of mercury in aquatic ecosystemsproperties, levels, cycle and determination,” Chem. Listy, vol. 100, pp. 862-876, 2006.

[5] P. Pelcová, H. Dočekalová, A. Kleckerová, "Determination of mercury species by the diffusive gradient in thin film technique and liquid chromatography - atomic fluorescence spectrometry after microwave extraction," Anal. Chim. Acta, vol. 866, pp. 21-26.

[6] V. Smolíková, P. Pelcová, J. Hedvábný, L. Zlámalová, A. Ridošková, "Modification of electrothermal atomic absorption spectrometry for determination of arsenic in high salinity samples," in Proceeding of $25^{\text {th }}$ International PhD students conference (MENDELNET 2018), 2018, pp. 527-531. [Online]: Available: https://mendelnet.cz/pdfs/mnt/2018/01/112.pdf. [2019-07-25] 